\title{
Assessment of the damping efficiency of a new type of concrete wall block
}

\author{
Izabela Adamczyk ${ }^{1}$
}

\begin{abstract}
:
The article presents a solution for a new type of concrete wall block, which transfers loads from the entire building and additionally dampens vibrations from the external medium directly inside the block. The shape of the new type of concrete block was described, as well as the method of its execution and basic application. An important element was the development of the location of the through holes in the block, the shape of which and the possibility of filling them allowed for the dispersion of the propagating mechanical wave directly in the block. A test was carried out to determine the reduction of vibrations on the test stand, and the average values of damping between the walls for wall blocks without filling $(\mathrm{N})$ and with filling $(\mathrm{NW})$ were calculated. To compare the results, the test was performed for PBF-24 hollow bricks available on the market. It was found that the shape of the new type of hollow block improves vibration damping more than 4 times, and filling the block with a recycled composite mixture increases the damping to 7.5 times more compared to the PBF-24 block. Another advantage was the management of recycling materials, which directly translates into environmental protection.
\end{abstract}

\section{KEYWORDS:}

concrete wall block; vibration reduction; recycling

\section{Introduction}

The traditional concrete block is widely used in general construction, land and water, in plastered and unplastered masonry structures, carrying and not transmitting loads. It is also widely used in the construction of external and internal aboveground structural walls as well as internal and external foundation walls, single-layer, retaining or basement walls, and as lost formwork, replacing typical wooden or metal formwork.

The production of a concrete block is a simple, multi-stage process. In the first stage, molds are designed, usually made of steel, which, after appropriate lubrication from the inside, are filled with the designed concrete mix. Then, the concrete mix is compacted in a mold by vibration, cared for and demolded. The last step is cleaning the surface of the block and obtaining a ready-to-use construction product. Due to their large dimensions, concrete blocks directly contribute to increasing the speed of wall insertion and reducing the number of joints, while reducing the number of thermal bridges between them. Concrete blocks have various types of through holes of various sizes, shapes and numbers, usually arranged alternately (staggered), which not only minimizes thermal bridges inside the block, but above all significantly reduces weight compared to a traditional concrete block. Another advantage of concrete blocks is the possibility of placing various types of thermal insulation in the through holes in the form of polyurethane foam, polystyrene or mineral wool, they are then called hollow blocks with filling. An example of this are concrete-expanded clay blocks: Hotblok with polystyrene filling, Leier 
Monolit 25 filled with polystyrene granules, or Purblok filled with polyurethane foam. They are intended for the construction of partitions, foundation walls, load-bearing walls in low-story and multi-story buildings, as single-layer walls. Due to the exposure of buildings to various types of dynamic impacts caused by human activity, for example as a result of machinery or vehicle traffic [1], an attempt was made to develop a new type of hollow block, the additional function of which will be to reduce external mechanical vibration.

\section{The shape of a new concrete wall block}

On the basis of a cuboid, a new shape of the block was developed, allowing the construction of structural elements of the walls, at the same time designing curvilinear through holes and grooves in it. The new hollow brick is intended to fill the holes with a designed recycled composite mixture made of recycled ingredients such as: SBR rubber granulate, eagle powder, fraction $0 \div 1 \mathrm{~mm}$, base eagle, fraction $0.8 \div 2 \mathrm{~mm}$ and $2 \div 4 \mathrm{~mm}$, and polyethylene terephthalate in form of PET flakes which are the matrix element, the whole was joined with a polyester resin $[2,3]$. The used rubber from used car tires or colored PET flakes from used food packaging make it possible to use this waste on a large scale. Such a solution directly contributes to the protection of the environment [4]. The filling enables the simultaneous fulfillment of the requirements for traditional openwork wall blocks and the possibility of damping external dynamic vibrations, which are not transferred directly to the structure. The through holes were placed in the interior of the brick asymmetrically (overlapping), ensuring continuity for the designed recycling composite mixture, in accordance with the patent no. 235427, entitled: "Openwork wall block" (Fig. 1) [5]. The through-holes are designed in such a way that, after rotating the block alternately by 180 degrees, they allow for a combination of arranging them next to each other, ensuring the continuity of the barrier for external vibrations.

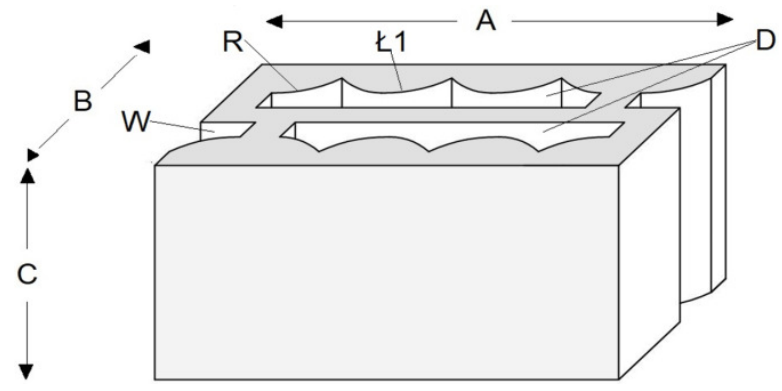

Fig. 1. The shape of a wall block with non-linear internal openings and butt locks. A - length of the wall block, $\mathrm{B}$ - width of the wall block, C - height of the wall block, D - through holes through the entire height of the block, $七 1$ - arch for the through hole, $\mathrm{R}$ - radius for the through hole, $\mathrm{W}$ - groove of the wall block serving as a place for a lock connecting hollow bricks [5]

The newly designed shape of the concrete wall block enables easy and quick construction of foundation and retaining walls. The block is laid in layers with a traditional overlap, jointed vertically and horizontally with a $10 \div 15 \mathrm{~mm}$ cement joint. In addition, the brick has two so-called "Grooves" W (Fig. 1), which allow the horizontal connection of the next blocks on the so-called "Lock" [6]. The blocks are then locked with each other and provide horizontal stabilization. Directly at the construction site, the inlets will be filled with the designed recycled composite mixture. Good technical parameters of the new type of concrete wall block were ensured by the technology of its production, which was based on the selection of appropriate natural minerals and ingredients obtained from recycling. The very shape of the concrete wall block was designed to act as a load-bearing element and, additionally, that its internal geometry would allow the scattering of mechanical waves propagating through the erected wall. A steel form for the brick was designed and made, and a concrete mix was designed for its execution. The tradi- 
tional technological process of producing a newly designed concrete wall block is: filling the mold with concrete mix, its proper compaction on a vibrating table, proper concrete care for 28 days, demolding, checking the correct dimensions and cleaning the surface of the block. The basic technical parameters of the new type of brick without filling are: dimensions $240 \times 240 \times 490 \mathrm{~mm}$, weight $43.8 \mathrm{~kg}$, flatness of the laying surface $0.3 \mathrm{~mm}$, parallelism of the laying surface $0.6 \mathrm{~mm}$, standard compressive strength $26.7 \mathrm{MPa}$.

\section{Study of the reduction of vibrations propagating through a wall block}

In order to determine the reduction of vibrations by the concrete wall, a test stand was made in accordance with Figure 2. The test was carried out for new type of concrete wall blocks without filling $(\mathrm{N})$ and filling with a recycled composite mixture (NW). To assess the effectiveness of the damping of the new hollow bricks, they were compared with the CJ Block PBF-24 public brick, the weight and dimensions of which are comparable to the new type of hollow brick [7]. In order to level the micro-inequalities of the substrate, the test stand was placed on a rubber mat with a thickness of $1 \mathrm{~mm}$.

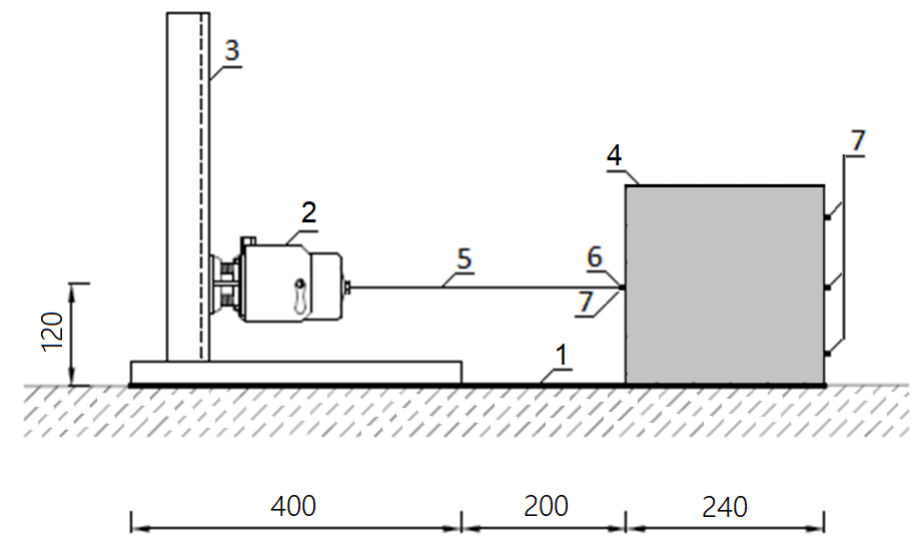

Fig. 2. Test stand: 1 - rubber mat, thickness $1 \mathrm{~mm}, 2$ - force inducer K2007E01, 3 - tripod, 4 - concrete wall block, 5 - rod M6 fixing the force sensor, 6 - force sensor 2311-1, 7 - accelerometers marked in the test with numbers from $P_{1}$ to $P_{6}$

The first accelerometer $\mathrm{P}_{1}$ was set in the central point of the front wall of the block, and the exciting force (inductor 2 in Fig. 2) causing the vibrations was applied at a distance of $1 \mathrm{~cm}$ from the center of the wall at point $S$. The remaining accelerometers $P_{2}$ to $P_{6}$ were placed on the rear wall of the block according to the diagram shown in Figure 3. The test was carried out for the selected sixteen frequencies: $8,16,32,64,128,256,512,1000,1500,2000,2500,3000,3500$, $4000,4500,5000 \mathrm{~Hz}$, and the voltages were respectively: from 8 to $512 \mathrm{~Hz}-0.3 \mathrm{~V}$, from 1000 to $3000 \mathrm{~Hz}-0.8 \mathrm{~V}$ and from 3500 to $5000 \mathrm{~Hz}-0.9 \mathrm{~V}$. The minimum and maximum acceleration values for selected points: on the front wall, directly with the application of force $\left(\mathrm{P}_{1}\right)$ and on the opposite, rear wall in its center $\left(\mathrm{P}_{6}\right)$, were read with the Simens LMS TestLab 17 software.

Based on the formulas (1) and (2), the peak-to-peak acceleration values and the relative damping values for the selected frequencies of the successive series of blocks were calculated. The peak-to-peak values of accelerations qmi at selected points $\mathrm{P}_{1}$ and $\mathrm{P}_{6}$ were determined for individual frequencies, which were calculated according to the formula (1). The relative value of attenuation $w_{t m i}$ was calculated according to the formula $(2)[8,9]$. On the basis of the arithmetic mean, the mean relative values of the attenuation wtmśr at the center point of the rear wall of the $\mathrm{P}_{6}$ blocks were calculated. In this way, the values of attenuation at the analyzed frequencies for the tested N, WN and PBF-24 blocks were calculated. 
a)
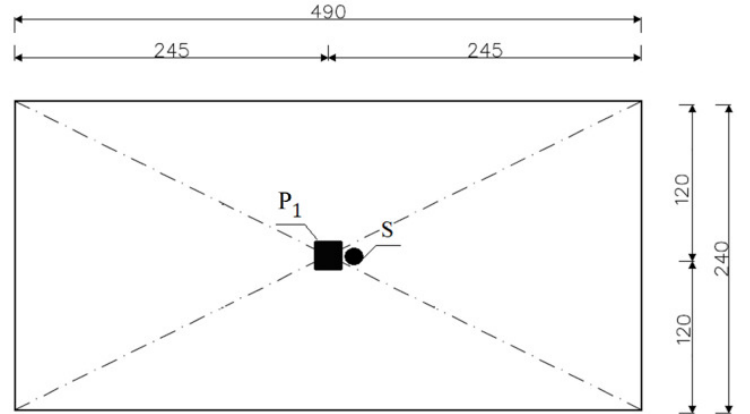

b)
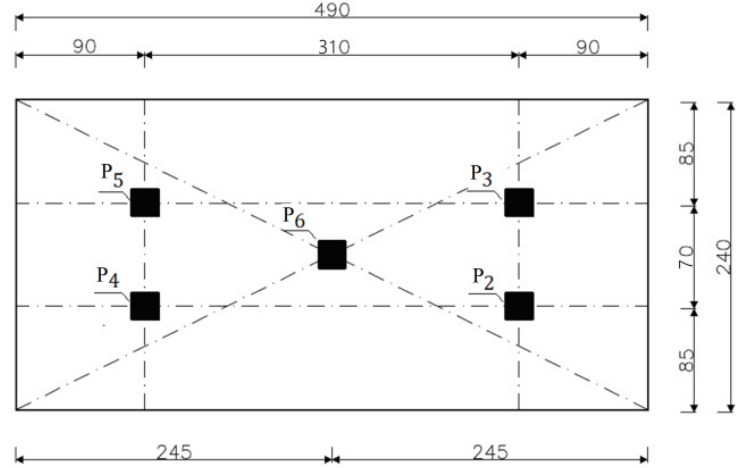

c)

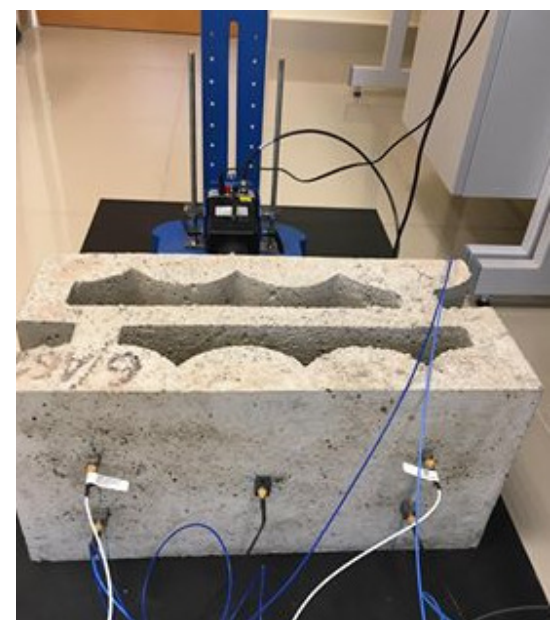

Fig. 3. Scheme of the arrangement of sensors on the walls of concrete blocks: a) front wall - accelerometer at point $P_{1}$, force sensor at point $S, b$ ) rear wall - accelerometers at points $P_{2}$ to $\left.P_{6}, c\right)$ view of the test stand

Relative damping value $w_{t m i}$ :

$$
W_{t m i}=\left(1-\frac{q_{m 6}}{q_{m 1}}\right) \cdot 100[\%]
$$

where: $q_{m 1}$-acceleration amplitude at point $\mathrm{P}_{1}$ in the geometric center of the front wall of the hollow brick - peak-to-peak value $\left[\mathrm{m} / \mathrm{s}^{2}\right], q_{m 6}$ - acceleration amplitude at the $\mathrm{P}_{6}$ measurement point of the brick rear wall - peak-to-peak value $\left[\mathrm{m} / \mathrm{s}^{2}\right]$. 
Peak values $q_{m i}$ :

$$
q_{m i}=\frac{\left[\left|q_{i \max }\right|-\left|q_{i \min }\right|\right]}{2}\left[\mathrm{~m} / \mathrm{s}^{2}\right]
$$

where: $q_{i \min }-$ minimum acceleration value $\left[\mathrm{m} / \mathrm{s}^{2}\right]$ at $\mathrm{P}_{i}$ for $i=1$ or $6, q_{i \max }-$ maximum acceleration value $\left[\mathrm{m} / \mathrm{s}^{2}\right]$ at $\mathrm{P}_{i}$ for $i=1$ or 6 .

The diagram (Fig. 4) compares the results of the average relative damping values for a new type of concrete wall block without filling $(\mathrm{N})$ and with filling (NW) and the PBF-24 block between their front and rear walls in its central part (readings from $\mathrm{P}_{1}$ and $\mathrm{P}_{6}$ accelerometers).

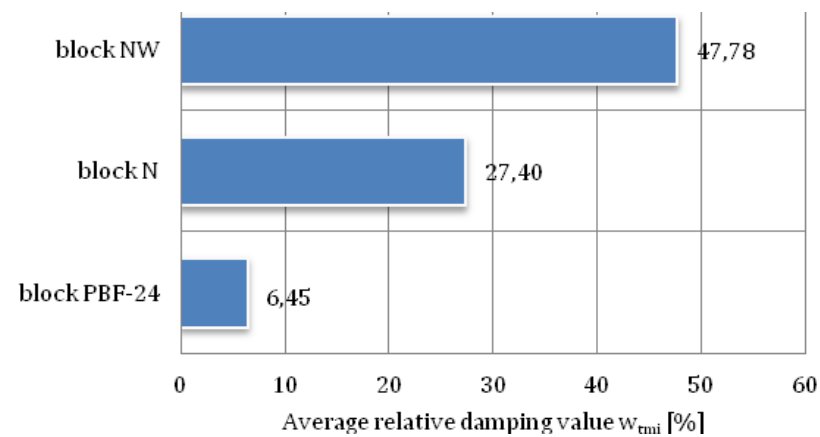

Fig. 4. Average relative attenuation values for hollow blocks: new type without filling (N), new type with filling with recycled composite mix (NW) and PBF-24

\section{Conclusions}

The developed a new type of concrete block based on a cuboid has typical external dimensions. It is distinguished by internal through holes designed in such a way that they can dissipate vibrations caused by the external medium already inside the brick. An additional advantage of the brick is the possibility of filling through holes with a designed recycling composite mixture made of recycled materials: SBR rubber granulate, polyethylene terephthalate in the form of PET flakes and a weld in the form of polyester resin. Based on the research on the reduction of vibrations propagating through the wall of the hollow block, it was found that the average relative value of attenuation wtmi for selected frequencies is: $27.4 \%$ for a new type of hollow brick without filling $(\mathrm{N})$, and for a new type of brick with a filling with a recycled composite mixture (NW) 47, 78 and $6.45 \%$ for the control block PBF-24. It was found that the PBF-24 concrete block dampens vibrations caused by the external medium by $6.45 \%$, the new type of hollow block without filling $(\mathrm{N})$ more than 4 times more, and the new type block with filling (NW) almost 7.5 times more. This means that the shape of the block itself has a direct impact on the improvement of vibration damping properties, and additionally, its filling with a designed recycling composite mixture may constitute a good barrier to mechanical vibrations formed in the soil medium. On this basis, it can be concluded that the developed new type of concrete block can be used for the construction of structural elements, especially industrial and engineering buildings, primarily in foundation walls, e.g. for machines or as a foundation for industrial or residential construction located near the tracks.

\section{References}

[1] Major M, Minda I., Drgania i oddziaływania dynamiczne na budynki i budowle, Zeszyty Naukowe Politechniki Częstochowskiej 2016, Seria Budownictwo 22, 223-237.

[2] Adamczyk I., The analysis of the compression strength of concrete modified with rubber granules SBR and polyethylene terephtalate, Zeszyty Naukowe Politechniki Częstochowskiej 2019, Seria Budownictwo 25, 9-14. 
[3] Adamczyk-Królak I., Guma i politereftalan etylenu z recyklingu - składniki materiałów budowlanych, Zeszyty Naukowe Politechniki Częstochowskiej 2018, Seria Budownictwo 24, 9-12.

[4] Major M., Major I., Wykorzystanie odpadów gumowych w budownictwie zrównoważonym, Budownictwo o Zoptymalizowanym Potencjale Energetycznym 2014, 2(14).

[5] Adamczyk I., Major M., Patent nr 235427 PCz, pt. „Ażurowy pustak ścienny”.

[6] Adamczyk I., Major M., Patent nr P.433857 PCz, pt. „Wkładka do ażurowych pustaków ściennych”.

[7] Specyfikacja techniczna PBF-24, CJ Blok.

[8] Morel J., Drgania maszyn i diagnostyka ich stanu technicznego, Polskie Towarzystwo Diagnostyki Technicznej, 1987.

[9] Kucharski T., System pomiaru drgań mechanicznych, Wydawnictwo WNT, 2018.

\section{Ocena redukcji (tłumienia) drgań w nowych typach betonowych pustaków ściennych}

\section{STRESZCZENIE:}

Betonowe pustaki są powszechnie stosowanym materiałem w budownictwie, które cechują się stosunkowo dobrymi gabarytami, co bezpośrednio przekłada się na szybkość budowania m.in. ścian fundamentowych. W artykule przedstawiono opracowanie rozwiązania nowego typu betonowego pustaka ściennego, który poza swoją podstawową funkcją przenoszenia obciążeń z całego budynku, dodatkowo tłumi drgania pochodzące z ośrodka zewnętrznego bezpośrednio wewnątrz pustaka. Opisano kształt nowego typu pustaka betonowego, sposób jego wykonania i podstawowe zastosowanie. Istotnym elementem było opracowanie umiejscowienia otworów przelotowych w pustaku, których kształt i możliwość ich wypełnienia pozwoliły na rozproszenie propagującej fali mechanicznej bezpośrednio w pustaku. Przeprowadzono badanie w celu określenia redukcji drgań na wykonanym stanowisku badawczym oraz obliczono średnie wartości tłumienia między ściankami w centralnym ich punkcie dla nowego typu betonowych pustaków ściennych bez wypełnienia $(\mathrm{N})$ oraz z wypełnieniem recyklingową mieszanką kompozytową (NW). Dla porównania wyników badanie wykonano dla dostępnych na rynku pustaków PBF-24. Stwierdzono, że sam kształt nowego typu pustaka poprawia tłumienie drgań ponad 4-krotnie. Natomiast wypełnienie pustaka recyklingową mieszanką kompozytową zwiększa tłumienie do 7,5 razy więcej w odniesieniu do pustaka PBF-24. Dodatkowym atutem było zagospodarowanie materiałów recyklingowych, co bezpośrednio przedkłada się na ochronę środowiska.

SŁOWA KLUCZOWE:

betonowy pustak ścienny; redukcja drgań; recykling 